\title{
THE INFLUENCE OF MARKETING MIX ON GUEST PURCHASE DECISIONS AT GUMILANG REGENCY BANDUNG HOTEL
}

\author{
Mustika Permatasari \\ Food and Beverage Study Program \\ Politeknik Pariwisata Palembang \\ Palembang, Indonesia \\ mustika.permata1986@gmail.com
}

\begin{abstract}
Tourism business are developed rapidly in Indonesia and have contributed substantially so it can be said that tourism is the largest contributor in the service sector of international tourism. Hospitality service is one of the accommodation services that support the tourism industry. Therefore, the tourism industry without the presence of hotels will face some obstacles. This research is a quantitative approach with descriptive verification method. This study was conducted to hotel guests who stay a population of 53.339 and a sample of 100 guests. The analysis techniques used is multiple regression analysis. The results of this study indicate that: 1) Marketing Mix at Gumilang Regency Hotel is quite good; 2) Guest Purchasing Decisions at Gumilang Regency Hotel are quite good; 3) The Effect of Marketing Mix on Guest Purchasing Decisions at Gumilang Regency is quite good. Simultaneously there is a significant relationship between marketing influence the decision of a guest's stay at $58,4 \%$ and $41,6 \%$ were influenced by other variables not studied.
\end{abstract}

\section{Keywords-Marketing Mix, Guest Purchasing Decision}

\section{INTRODUCTION}

Tourism is categorized into the world's largest industry group (the world's largest industry), around eight percent of exports of goods and services, generally from the tourism sector. So that it can be said that tourism is the biggest contributor in the service sector in international tourism. The role of tourism in improving the country's economy and people's welfare cannot be doubted. Tourism is the only economic activity that can withstand economic constraints that in recent years continue to be seen and felt as a result and become one of the options to be able to play a role as a development tool in realizing national development.

The city of Bandung is the largest metropolitan city in West Java as well as being the capital of the province. The city of Bandung is still a tourist destination for many tourists. Various types of tours are available in the city of
Bandung, we call it Shopping Tours, Culinary Tours, Cultural Tourism, and various recreational and natural tourism places. Various public transportation facilities have sprung up and made it easy to access to or out of the city of Bandung. The Bandung City Government pays attention to the development of tourism in the city of Bandung with the aim of obtaining a positive impact from the tourism industry such as the road to tourist attractions which will certainly have an impact on improving the economy of the community, and making the tourism industry a potential source of regional income.

Marketing has become a very important subject in our daily lives as the economy develops. Marketing is a human activity that is directed to meet needs and desires through an exchange process.

In the sale of accommodation services namely hospitality, the increase in sales of room services is highly dependent on the marketing mix that the company carries out where the marketing mix carried out can generate feedback for the company. The success of a company is determined by the company's management capabilities in utilizing the opportunities that exist in the community and managing the existing marketing mix. In the marketing mix service company according to Nirwana (2004: 48) in the form of: "Products, prices, promotion, distribution/place, process, people/participants and promises are factors that can influence and encourage a consumer to consume services offered." Knowledge needs many factors of marketing mix to increasingly recognized by entrepreneurs because with the right marketing mix strategy a company can achieve its goals. Marketing mix is a tool that is used by a company to influence purchasing decisions of prospective customers or customers. The target, they decided to buy the product offered The concept that is usually used as a competitive advantage by a company is a Marketing Mix, which consists of 7 variables which are the core of the marketing system, namely excellence in terms of product, price, place, marketing, human resources (people), process, and physical appearance. These things are usually processed 
by a company so that it can become an advantage of the company in order to enter competition in an increasingly tight market.

Companies must be able to formulate the marketing mix appropriately, therefore the company cannot ignore opinions or input from consumers. The existence of consumers has an influence on the achievement of the ultimate goal of the company, namely the acquisition of profits through the purchase of products. Companies must know the factors that can influence consumers in making product purchase decisions. The rise of hotel growth rates cannot be separated from the opportunity to increase oocupancy, especially hotels in strategic areas.

\section{LITERATURE REVIEW}

\section{A. Management and Marketing}

According to Sudarwan and Yunan Danim (2010: 18) argues that: Management as a typical process, which consists of actions planning, organizing, mobilizing, and supervising, is carried out to determine and achieve the goals that have been set through the use of resources human resources and other sources to achieve certain goals. Management is the process of achieving organizational goals by carrying out activities from four main functions, namely planning, organizing, leading and controlling.

The definition of management according to Handoko (2012: 8) explains that: Management is the process of planning, organizing, directing and supervising the efforts of members of the organization and the use of other organizational resources in order to achieve organizational goals that have been set. Based on the above opinions can be taken the meaning that management means the optimization of resources or management and control. Resources that are optimized, managed, and controlled include human resources and other supporting sources. The process includes steps for planning, organizing, implementing and controlling.

Management for each organization or institution is a key element that must be carried out by every leader of the organization or institution. The leaders act as managers so they must use organizational resources, finance, equipment and information as well as human resources in achieving the goals that have been set beforehand. Human resources are the most important resource for every organization. Organizational goals that have been set (state goals) means that the leaders or managers of any organization try to achieve a variety of specific end results, of course must be unique to each organization.

Marketing is one of the main activities carried out by the company in order to achieve the goal of maintaining survival to develop, and gain profits. Marketing is also an important factor in meeting consumer needs. For this reason marketing activities must be able to provide customer satisfaction if the company wants its business to continue to run or wants consumers to have a good view of the company. Definition of marketing according to William J. Stanton cited by Swastha and Handoko (2004: 4):
"Marketing is an overall system of business activities aimed at planning, pricing, promoting, and distributing goods and services that can satisfy the needs of both existing buyers and potential buyers.

\section{B. Marketing Mix}

Definition of marketing mix according to Kotler and Armstrong (2006: 62): "Marketing mix is a collection of controlled, active marketing tools that the company combines to produce the desired response in the target market." The definition of marketing mix according to Buchari (2009:205), according to Philip Kotler and Gary Armstrong in his book Principle of Marketing is a set of controlled marketing tools that are integrated by companies to produce responses that are desired by the target market.

The service mix strategy is the development of a traditional marketing mix consisting of Product, Price, Place and Promotion. The development progresses to $7 \mathrm{P}$ with the addition of Physical Evidence, Process and People. The last three elements namely Physical Evidence, Process and People are elements of a marketing mix that is specifically intended for services. Based on the description above it can be said that the marketing mix is a group of variables consisting of products, prices, promotions, distribution channels, human resources, processes and physical infrastructure that can be implemented by the company to influence the demand for its products.

1. Product according to Kotler and Keller (2009: 358) in his book provide the following understanding of products: "A product is anything that can be offered to the market to satisfy a want or need. Product that is marketed including physical goods, services, experience, events, persons, places, properties, organizations, informations, and ideas". This means that the product is everything that can be offered to the market to satisfy desires and needs. There are two types of products, tangible and intangible. Product attributes include type, quality, design, features, brands, packaging size, service, warranty and rewards. Product elements related to planning in producing a final product for consumers.

2. Price according to Kotler \& Keller (2009: 446) said the price is the only element that produces revenue; the others produce costs ". This means that prices are one of the elements that generate income and others produce costs. Price attributes include price lists, discounts, special price discounts, payment periods and credit terms. Prices directly affect the company's profit.

3. Location according to Kotler and Armstrong in his book (2008: 48) define the location as "Company activities that make products available to target consumers". Company activities so that the products are easily available to the target customers. This means that the distribution channel or location variables not only emphasize the location of the company, but also about the problem of determining the location and company, whether or not the location is reached. The strategic 
location of the company is key to the company's ability to attract consumers.

4. Promotion means activities that merits the product and market competition to buy it. Promotion is an activity that communicates product excellence and persuades the target market to buy it, Kotler and Armstrong (2008: 48).

5. According to Ratih Hurriyati (2010: 62), the definition of people in the service marketing mix is all actors who play a role in the the presentation of services so as to influence the perception of buyers. The elements of "people" are company employees, consumers and other consumers in the service environment. All employee attitudes and actions and even employee dressings and employee appearances have an influence on consumer perception or service encounter. That means the service organization must recruit and retain employees who have the skills, attitudes, commitment and ability to foster good relationships with consumers. People in this service are people who are directly involved in running company activities and are factors that play an important role for all organizations.

6. According to Zeithalm and Bitner, who was quoted by Ratih Hurriyati (2010: 64) stated that the process is all the actual procedures, mechanisms and flow of activities used to deliver services. The process in services is a major factor in the marketing mix of services such as service customers will often market the service delivery system as part of the service itself.

7. According to Zeithalm and Bitner, who was quoted by Ratih Hurriyati (2010: 63) states that physical means is a matter that significantly contributes to consumers' decisions to buy and use the services offered. The elements included in physical facilities include the physical environment, in this case the physical building, equipment, equipment, logos, colors and other items that are combined with the services provided such as tickets, covers, and labels.

\section{Purchase Decision}

Purchasing decisions are individual activities that are directly involved in making decisions to make purchases of products offered by sellers. Understanding the purchase decision, according to Kotler \& Armstrong (2012: 226) is the stage in the decision making process of the buyer where the consumer actually buys. Decision making is an individual activity that is directly involved in obtaining and using the goods offered.

The following are the five stages of the consumer purchasing process at:

1. Introduction to problems. The buying process begins when consumers recognize a problem or need. Consumer needs can be influenced by internal stimuli or external stimuli. Marketers need to identify circumstances that trigger certain needs.

2. Search for information. After recognizing their needs, consumers will be encouraged to find more information. A lighter information search situation is called strong attention. At this level one only becomes more sensitive to information about the product.

3. Alternative evaluation. First, consumers try to meet a need. Second, consumers seek certain benefits from product solutions. Third, consumers view each product as a set of attributes with different abilities in providing benefits that are used to satisfy those needs.

4. Purchase decision. In the evaluation stage, consumers form preferences for brands in a collection of choices. Consumers may also form intentions to buy the most preferred product.

5. Post-purchase behavior. The last process is the behavior after buying, in this case we see satisfaction after buying and actions that can affect the next behavior.

\section{RESEARCH MethodOLOGY}

The object of this study is the perception of business guests on the marketing on guest purchase decisions. The independent variable of this study is the marketing mix (X) consisting of Products (X1), Price (X2), Promotion (X3), Location (X4), Person (X5), Process (X6) and Physical appearance (X7), then the dependent variable in this study is the purchase decision which consists of product specifications, amount of price, marketing.

The research method used in this research is descriptive and verification research methods. According to Freddy Rangkuti (2006: 17), descriptive research method is a research method that aims to provide an overview of the state of the company to be processed into data needed by the researcher.

The samples used in this study were consumers who stayed during the study. The sampling technique in this study uses the Simple Random Sampling technique, which is a simple random sampling method through a list of random numbers, so that each element of the population has the same opportunity to be selected as a member of the sample to be studied, Supranto (2004: 75$)$. So the sample in this study was 100 people.

Data Collection Method. Data collection methods used in this study are:

1. Interview

The interview was conducted by communicating directly with the Gumilang Regency Hotel marketing manager to obtain data on company profiles, marketing and sales techniques, the number of guests coming in the last 3 years, the number of rooms available.

2. Observation

Observations are made by observing directly the object under study, namely Gumilang Regency Hotel, especially regarding products, renovation of hotel buildings and promotional activities and the level of visit of guests who come to stay.

3. Questionnaire Method

In this study the questionnaire was used as the main method to obtain the data given to. The questionnaire method is used because it is more practical and can be 
shared simultaneously with the respondent. In addition, the instrument or questionnaire can be answered by the respondent according to the speed of each and for all respondents given the same question.

4. Literature Study

Literature study is the collection of data and information relating to theories and concepts related to the problem of the variables studied which consist of products, prices and promotions as well as their influence on guest visiting decisions.

\subsection{Data Testing}

Considering the data collection was collected using a questionnaire, the respondents' sincerity in answering questions was very important in the study. The validity or validity of a social research result is largely determined by the measuring instrument used. To overcome this, two types of testing are needed, namely the validity test (test of validity) and reliability test (test of reliability), to test the sincerity of the answers from the respondents.

1. Validity Test

Validity is a measure that shows the level of validity or accuracy of an instrument. This means that the instrument is able to measure what is desired. In this study validity test was used by using Pearson's correlation formula as follows :

$$
r=\frac{N\left(\sum X Y\right)-\left(\sum X \sum Y\right)}{\sqrt{\left[N \sum X^{2}-\left(\sum X\right)^{2}\right]}\left[N \sum Y^{2}-\left(\sum Y\right)^{2}\right]}
$$

2. After obtaining the validity data of the measuring instrument, then a reliability test is conducted which aims to see how much reliability the measuring instrument is. The purpose of the reliability test is to measure the extent to which results or measurements are fixed, trustworthy and free from measurement errors. In this study the reliability test using the Brown-Brown method is as follows:

$$
r_{11}=\left(\frac{n}{n-1}\right)\left(1-\frac{\sum \sigma_{t}^{2}}{\sigma_{t}^{2}}\right)
$$

Next calculating the reliability coefficient:

$$
r=\frac{1+\alpha}{2 \alpha}
$$

3.2 Data analysis method is a method used to process research results in order to obtain an instrument and conclusions. The data analysis method used in this study is multiple linear regression analysis. Multiple linear regression analysis is used to determine the relationship between independent variables and the dependent variable, namely between Products (X1), Price (X2), Promotion (X3), Location (X4), Person (X5), Process (X6) and Physical appearance (X7), against the purchase decision (Y). In addition to knowing the extent of the influence between independent variables and dependent variables. The multiple linear regression equations used in this study are:

$\mathrm{Y}=\mathrm{a}+\mathrm{b}_{1} \mathrm{X}_{1}+\mathrm{b}_{2} \mathrm{X}_{2}+\mathrm{b}_{3} \mathrm{X}_{3}+\ldots \ldots \ldots \ldots \ldots \mathrm{b}_{6} \mathrm{X}_{6}+\mathrm{b}_{7} \mathrm{X}_{7}+\mathrm{e}$

To prove the validity of the hypothesis must pass several truth tests, including the following:

Simultaneous Test

a. F test, which is a test to determine the effect of the independent variables together (simultaneously) on the dependent variable. If the calculation results of $\mathrm{F}$ count $<\mathrm{F}$ table then Ho is accepted and $\mathrm{H}_{1}$ is rejected so that it can be said that the variables of the regression model are not able to explain the dependent variable. Conversely, if $\mathrm{F}$ arithmetic $>\mathrm{F}$ table then $\mathrm{Ho}$ is rejected and $\mathrm{H}_{1}$ is accepted, it can be concluded that the seven independent variables $x(x 1, x 2, x 3, x 4, x 5, x 6, x 7)$ together have a significant influence on sales volume. Thus it can be said that the independent variable of the multiple linear regression model is able to explain the dependent variable.

b. Determination Coefficient, which is to find the magnitude of the coefficient of determination of the independent variable on the dependent variable.

\section{Partial Test}

$\mathrm{T}$ test, which is a test to influence the influence of independent variables partially on the dependent variable. If $\mathrm{t}$ counts $>\mathrm{t}$ table, then $\mathrm{Ho}$ is rejected and $\mathrm{H}_{1}$ is accepted, thus the independent variable can explain the dependent variable in the model. Conversely, if $t$ count $<\mathrm{t}$ table, then Ho is accepted and $\mathrm{H}_{1}$ is rejected, thus the independent variable cannot explain the dependent variable or in other words there is no influence between the two variables. 


\section{RESEARCH ANALYSIS}

4.1 Descriptive Analysis of the Marketing Mix at Gumilang Regency Hotel. The results are as follows:

1. Respondents' Response Regarding Marketing Mix

\begin{tabular}{|c|c|c|c|}
\hline No. & Variable $\mathrm{X}$ & Indicator & Score \\
\hline \multirow[t]{7}{*}{1.} & Product & - The interesting of room & 419 \\
\hline & & - Variaty of room & 377 \\
\hline & & $\begin{array}{l}\text { - The cleanliness and } \\
\text { comfortable }\end{array}$ & 376 \\
\hline & & - The complete facilities & 355 \\
\hline & & - The quality of room & 397 \\
\hline & & $\begin{array}{l}\text { - The suitable within } \\
\text { advertising and actual }\end{array}$ & 353 \\
\hline & & - The service of hotel & 401 \\
\hline \multirow[t]{4}{*}{2.} & Price & - The suitable of price & 414 \\
\hline & & $\begin{array}{l}\text { - The suitable facilities and } \\
\text { price }\end{array}$ & 423 \\
\hline & & - The frequent of discount & 395 \\
\hline & & - Easy in payment & 395 \\
\hline \multirow[t]{4}{*}{3.} & Location & - Location of hotel & 392 \\
\hline & & - Easy way to reach hotel & 384 \\
\hline & & $\begin{array}{l}\text { - Suitable time to reach the } \\
\text { hotel }\end{array}$ & 357 \\
\hline & & $\begin{array}{l}\text { - The suitable within } \\
\text { comfortable and facilities }\end{array}$ & 377 \\
\hline \multirow[t]{6}{*}{4.} & Promotion & - Proper way to promote & 384 \\
\hline & & - Discount rate & 376 \\
\hline & & $\begin{array}{l}\text { - Sales promotion and } \\
\text { publicity }\end{array}$ & 401 \\
\hline & & - Target market & 353 \\
\hline & & - Publish information & 390 \\
\hline & & - Media promotion & 375 \\
\hline \multirow[t]{5}{*}{5.} & People & - Skill in service the guest & 336 \\
\hline & & - Implementation of SOP & 365 \\
\hline & & - Coordination within team & 362 \\
\hline & & - Attention to details & 390 \\
\hline & & $\begin{array}{l}\text { - Responsiveness to the } \\
\text { guest }\end{array}$ & 390 \\
\hline \multirow[t]{5}{*}{6.} & Process & - Operational activity & 407 \\
\hline & & - Handling complaint & 385 \\
\hline & & - Reservation process & 374 \\
\hline & & $\begin{array}{l}\text { - Standard of service } \\
\text { quality }\end{array}$ & 388 \\
\hline & & - Layout design & 362 \\
\hline \multirow[t]{5}{*}{7.} & $\begin{array}{l}\text { Physical } \\
\text { evidence }\end{array}$ & $\begin{aligned} & \text { Interior amd exterior } \\
\text { - } & \text { design }\end{aligned}$ & 383 \\
\hline & & - Employee appearance & 379 \\
\hline & & - Fully equipment & 391 \\
\hline & & - Professional credibility & 406 \\
\hline & & - Exterior capacity & 384 \\
\hline
\end{tabular}

2. Respondents' Response Regarding Purchase Decision

\begin{tabular}{|r|l|l|c|}
\hline No. & Variable Y & Indicator & Score \\
\hline 1. & $\begin{array}{l}\text { Purchase } \\
\text { Decision }\end{array}$ & $\begin{array}{l}- \text { The comfortable of facility } \\
\text { and room }\end{array}$ & 381 \\
\hline & & - Clearly information & 364 \\
\hline & & - The service & 364 \\
\hline & & - The frequent ti stay & 378 \\
\hline & & - Planning to stay & 384 \\
\hline
\end{tabular}

4.2 Effect of Products $\left(\mathrm{X}_{1}\right)$, Price $\left(\mathrm{X}_{2}\right)$, Location $\left(\mathrm{X}_{3}\right)$, Promotion $\left(\mathrm{X}_{4}\right)$, Person (X5), Process ( $\left.\mathrm{X}_{6}\right)$, Physical appearance $\left(\mathrm{X}_{7}\right)$ Against Purchase decisions $(\mathrm{Y})$.

The results of SPSS 20 software processing for multiple regression analysis are presented in the following table:

Table 1

Multiple Regression Analysis

\begin{tabular}{|c|c|c|c|c|}
\hline Variable & $\begin{array}{c}\text { Regresion } \\
\text { Coefisien }\end{array}$ & Std. Error & $\mathrm{t}$ & Sig. \\
\hline (Constant) & -1.509 & 0.438 & -3.446 & 0.001 \\
\hline $\mathrm{X} 1$ & 0.372 & 0.103 & 3.595 & 0.001 \\
\hline $\mathrm{X} 2$ & 0.066 & 0.091 & 0.732 & 0.466 \\
\hline $\mathrm{X} 3$ & 0.199 & 0.079 & 2.513 & 0.014 \\
\hline $\mathrm{X} 4$ & 0.155 & 0.107 & 1.454 & 0.149 \\
\hline $\mathrm{X} 5$ & 0.292 & 0.117 & 2.494 & 0.014 \\
\hline $\mathrm{X} 6$ & 0.181 & 0.085 & 2.127 & 0.036 \\
\hline $\mathrm{X} 7$ & 0.299 & 0.078 & 3.832 & 0.000 \\
\hline
\end{tabular}

Based on the results of the calculations in the table above, obtained the form of multiple linear regression equations as follows:

$$
\mathrm{Y}=-1.509+0.372 \mathrm{X}_{1}+0.066 \mathrm{X}_{2}+0.199 \mathrm{X}_{3}+0.155 \mathrm{X}_{4}+
$$
$0.292 \mathrm{X}_{5}+0.181 \mathrm{X}_{6}+0.299 \mathrm{X}_{7}$

The regression coefficient value on the independent variables illustrates that if the independent variable is estimated to increase by one unit and the other independent variable value is estimated to be constant or equal to zero, the value of the dependent variable is expected to rise or fall according to the independent variable regression coefficient.

Coefficient of Determination, The magnitude of the effect of the product (X1), price (X2), location (X3), promotion (X4), person (X5), process (X6), physical appearance $(\mathrm{X} 7)$ on stay decisions $(\mathrm{Y})$ can be indicated by the coefficient of determination with the formula as follows:

$$
\begin{aligned}
\mathrm{KD} & =\mathrm{R}^{2} \times 100 \% \\
& =(0,764)^{2} \times 100 \% \\
& =58.4 \%
\end{aligned}
$$


This means that the Product variable (X1), Price (X2), Location (X3), Promotion (X4), Person (X5), Process (X6), Physical Display (X7) gives $58.4 \%$ influence on the Stay Decision (Y). While the remaining $41.6 \%$ is the contribution of other variables besides the Product variable (X1), Price (X2), Location (X3), Promotion (X4), People (X5), Process

(X6), and Physical Display (X7).

\begin{tabular}{|c|r|r|r|r|}
\hline \multicolumn{5}{|c|}{ Model Summary } \\
\hline Model & \multicolumn{1}{|c|}{ R } & R Square & Adjusted R & Std. Error of \\
& & & Square & the Estimate \\
\hline 1 &, $764^{\text {a }}$ &, 584 &, 552 &, 33021 \\
\hline
\end{tabular}

a. Predictors: (Constant), Physical Evidence , Location, Process, Promotion, People, Product, Price

Testing Hypotheses in Overall (F Test)

To find out whether or not a significant influence of the independent variables on an independent variable is used the F test.

\begin{tabular}{|c|c|c|c|c|c|}
\hline F & df & F & Sig & Remark & Conclusion \\
\hline \multirow{2}{*}{18.429} & table & & & \\
\cline { 5 - 6 } & 7 & \multirow{2}{*}{2.111} & 0,000 & Ho & influence \\
\cline { 2 - 2 } & df2 $=$ & & & rejected & (Significant) \\
& & & & & \\
\hline
\end{tabular}

Rejection Area $\mathrm{H} 0$ at Joint Test. From the table above, the calculated $F$ value is 18,429 . Because the value of $F$ count $(18,429)>F$ table $(2,111)$, then Ho is rejected. Thus it can be concluded that simultaneously there is a significant effect of Product (X1), Price (X2), Location (X3), Promotion (X4), Person (X5), Process (X6), Physical Display (X7) Purchase Decision (Y).
Partial Hypothesis Testing (T Test)

\begin{tabular}{|c|c|c|}
\hline Variables & t count & Sig \\
\hline $\mathrm{X} 1$ & 3.595 & 0.001 \\
\hline $\mathrm{X} 2$ & 0.732 & 0.466 \\
\hline $\mathrm{X} 3$ & 2.513 & 0.014 \\
\hline $\mathrm{X} 4$ & 1.454 & 0.149 \\
\hline $\mathrm{X} 5$ & 2.494 & 0.014 \\
\hline $\mathrm{X} 6$ & 2.127 & 0.036 \\
\hline $\mathrm{X} 7$ & 3.832 & 0.000 \\
\hline
\end{tabular}

The variable $X_{1}$ has a calculated $t$ value greater than the value of $t$ table. Because the value of $t$ count $(3,595)>t$ table $(1,986)$, then Ho is rejected. The $\mathrm{X}_{2}$ variable has a calculated $t$ value greater than the value of $t$ table. Because the value of $t$ arithmetic $(0.732)<t$ table $(1,986)$, then Ho is accepted.

The $\mathrm{X}_{3}$ variable has a calculated $\mathrm{t}$ value greater than the value of t table. Because the value of $t$ count $(2,513)>$ $\mathrm{t}$ table $(1,986)$, then Ho is rejected. The $\mathrm{X}_{4}$ variable has a calculated $\mathrm{t}$ value greater than the value of $\mathrm{t}$ table. Because the value of $\mathrm{t}$ arithmetic (1.454) > t table (1.986), then Ho is accepted.

The $\mathrm{X}_{5}$ variable has a calculated $\mathrm{t}$ value greater than the value of $t$ table. Because the value of $t$ counts $(2,494)>t$ table $(1,986)$, then Ho is rejected. The $\mathrm{X}_{6}$ variable has a calculated $t$ value greater than the value of $t$ table. Because the value of $t$ arithmetic (2.127) $>t$ table (1.986), then Ho is rejected.

The $\mathrm{X}_{7}$ variable has a calculated $\mathrm{t}$ value greater than the value of $t$ table. Because the value of $t$ arithmetic (3.832) > $t$ table (1.986), then Ho is rejected.

\section{CONCLUSIONS AND RECOMMENDATIONS}

\subsection{Conclusions}

Based on the results of data analysis in order to test hypotheses and discuss the results of the study, conclusions can be put forward as follows:

1. The marketing mix (product, price, location, promotion, people, process and physical appearance) activities carried out by Gumilang Regency were considered quite well by guest respondents.

2. The decision to purchase guests at Gumilang Regency Hotel is considered to be quite good as seen from the five indicators, where the suitability of a comfortable place to stay is rated well with the highest value, availability of information and suitability of services offered with the lowest value. 
3. The influence of the marketing mix on guest purchasing decisions at Gumilang Regency Hotel in addition to influencing internal factors, while external factors play a role in guest factors in making the decision to stay overnight. Where the external influences of customers are covered by various security situations, the existence of government policies, the economic situation, the prevailing legal force in Indonesia, the state of the political situation, changes in banking exchange rates with foreign currencies, infrastructure, technological developments, cultural influences, reference groups, family factors, social class. In addition there are also other internal customer environmental factors which include customer resources, knowledge, attitude, motivation, involvement, self-concept, personality, value, and life style and so on.

\subsection{Suggestions}

To increase the influence of the marketing mix program on guest purchasing decisions at Gumilang Regency Hotel, based on the results of the research, suggestions are given as follows:

1. The marketing mix implementation activities need to be improved by increasing advertising marketing activities online and through social media. This is due to the growth of e-marketing where all guests can access via smartphones that are used daily. Marketing activities are carried out by promoting hotel products by obtaining benefits such as tea and coffee for afternoon snacks, so that this can also increase guest loyalty at Gumilang Regency Hotel.

The results of the study show that the most influential factor in purchasing decisions is the product. Products become the main factors that influence purchasing decisions. Gumilang Regency Hotel must be able to make innovations in the production process of products, especially food products in restaurants and also prioritize food hygiene to have a good / high influence on purchasing decisions. Other factors that influence purchasing decisions are the place or location where Gumilang Regency Hotel already has a strategic location but to attract customers, especially for the family or business market, this hotel needs to make banners or billboards with large size and clear in the Bandung City toll exit area.

The factors that influence other purchasing decisions are those where Gumilang Regency Hotel must increase the level of friendliness and smile with the waiter so that the customers are happy with the service at this hotel, such as

a quick check-in and check-out process and give a smile where guests don't have to wait too long to enter the guest room. The next factor that influences purchasing decisions is the process, preferably if Gumilang Regency Hotel implements the Standard Operating Procedure by conducting socialization twice in 1 month where this socialization also contributes to the Department Head to fill the role play activities contained therein, as for the module or hand book given to each employee as a handle in running operations in their respective departments so that the process of service to guests will be more optimal.

2. Development of innovation products is another factor that influences purchasing decisions is the physical appearance where Gumilang Regency Hotel includes hotels that have been established long enough that they must be able to carry out maintenance or maintenance carried out in guest rooms starting from the main bedroom, bathroom, living room and the guest dining room also maintains the building and completes other public facilities such as restaurants, swimming pools, children playgrounds, gyms and spas. This is supported by the availability of form maintenance or monitoring evaluation so that this maintenance program is carried out continuously. The explanation of innovative product development is as follows:

The actual condition of the Restaurant in Gumilang Regency

- Interior design has not followed trends/developments with current conditions

- The menu offered is less varied

- The restaurant area is not too large

In developing innovative products in Gumilang Regency, it is necessary to do this

- Make the interior design brighter and use a touch of local ethnicity

- Need to provide kids menu plus other children's facilities such as baby chairs, cutleries kids, etc.

- Create a more pleasant atmosphere by offering different themes every day, for example Sundanesse, Koreans, or Americans.

In developing the swimming pool products at Gumilang Regency, it is necessary to do this :

- Add children's play facilities such as sliders and water gun

- Complete the swimming equipment such as children's swimming goggles, towels, swimming tires and children's swim suits

- Make sales of snacks that can be consumed and liked by children such as snacks, soft drinks and milk

The actual Playground Children condition in Gumilang Regency:

- Lack of rides playing around the children playground

- There is no supervision when children play 
In developing Children Playground in Gumilang

Regency, it is necessary to do it :

- Hold live cooking activities every weekend where the available menus are children's favorite menus such as spaghetti, sandwiches, chicken wings etc.

- Hold attractive learning center activities such as coloring, Draw or make a craft.

The condition of the Gym and Spa is actually at

Gumilang Regency,

- Gym equipment is incomplete and without a Personal Trainer

- Gym area is a narrow place

- Spa packages offered are less varied

- Therapists who have no expertise in doing massage that makes guests feel comfortable

In developing the Gym and Spa in Gumilang Regency, it is necessary to do it:

- Using a professional Personal Trainer service

- The addition of Gym equipment is tailored to the needs of guests, especially for businessmen

- Creating a Balinese-themed Spa atmosphere where in general these traditional spas are in great demand

- Providing therapists who have spa certification

The Gumilang Regency sales that can be done using the internet, such as the Website, which contains hotel products, especially the advantages of the hotels that are owned are Children's Swimming Pool with Warm water and also a safe and comfortable children's playground. Ads on large websites such as:

1. Agoda,

2. King Room,

3. Travel site,

4. Aladdin,

5. Trip Advisor

6. Booking.com

Because the network owned by the website has worked with large companies such as Facebook, Google, Instagram and Twitter. In addition, the advantages possessed by the website are having a good searching engine, making it easier for consumers to access Gumilang Regency Hotel.

3. The effect of the marketing mix on guest purchasing decisions at Gumilang Regency Hotel can be done by improving the good image of this hotel. For example, by running a Corporate Social Responsibility program such as Blood Donation, Distribution of Basic Needs for orphans, Development of Drainage along the Setiabudhi road. Other programs by holding Table Top events where many invite Travel Agents to market travel products through this hotel. Or by expanding the On the Job Training program for Vocational Schools and making it an opportunity to hold venues for competency training.
[1] Algifari. 2000. Regresion Analysis, Theory, Case \& Solusion. BPFE UGM, Yogyakarta.

[2] Nirwana, (2004), Service Marketing Principal, Malang, Publisher Dioma.

[3] Buchari Alma, "Marketing Management and Service Marketing", CV. Alfabeta, Bandung: 2009

[4] Fandy Tjiptono, 2008. Marketing Strategy. Yogyakarta : Andi

[5] Freddy Rangkuti. 2006. Marketing Riset. Gramedia Pustaka Utama, Jakarta

[6] Hadi, Sutrisno. 2000. Methodology Research, Yogyakarta: Andi Yogyakarta

[7] Lovelock, Christoper H Lauren K Wright, 2007, Service Marketing Management (Translation), PT Indeks (GRAMEDIA GROUP). Jakarta

[8] Lupiyoadi, R. dan Hamdani A., 2009, Service Marketing Management, Second Edition, 191-200, Salemba Empat, Jakarta.

[9] Lupiyoadi, Rambat, 2001, Service Marketing Management, Salemba Empat, Jakarta. Kotler, Philip \& Keller, Amstrong, W. J., 2006. Marketing Management. Prentice Hall. New Jersey.

[10] Kotler, Philip and Gary Armstrong. 2012. Marketing Principal. Edisi 13. First Edition. Jakarta: Erlangga.

[11] Kotler, Philip and Kevin Lane Keller. 2012. Marketing Management 13. New Jersey: Pearson Prentice Hall, Inc.

[12] Zeithaml Valerie A, M.J. Bitner, (2013), Service Marketing, Firt Edition,USA: McGraw Hill Co.Inc. 